Çukurova Üniversitesi Mühendislik Fakültesi Dergisi, 36(2), ss. 557-569, Haziran 2021

Cukurova University Journal of the Faculty of Engineering, 36(2), pp. 557-569, June 2021

\title{
Tüketicinin Demografik Özelliklerinin Konut Satın Alma Davranışı Üzerindeki Etkileri
}

\author{
Hatice Kübra BAŞ ARAS ${ }^{1}$, Gözde TANTEKIN ÇELIK* ${ }^{* 1}$ \\ ${ }^{1}$ Çukurova Üniversitesi, Mühendislik Fakültesi, İnşaat Mühendisliği Bölümü, Adana
}

Geliş tarihi: 17.05.2021～Kabul tarihi: 30.06 .2021

Öz

Tüketicilerin konut satın alma davranışlarının ve bu davranışların altında yatan parametrelerin analiz edilmesi amacıyla yapılan bu çalışmada tüketicinin satın aldığı ya da almayı düşündüğü konutta önem verdiği nitelikler belirlenmiştir. Ayrıca tüketicinin cinsiyet, yaş, medeni durum, eğitim, gelir düzeyi ve meslek gibi demografik özelliklerinin konut tercihleri üzerindeki etkileri araştırılmıştır. Çalışmaya katılanların genelinin ihtiyaç sebebiyle konut satın almayı düşünen ve orta gelir düzeyine sahip bireylerden oluştuğu tespit edilmiştir. Elde edilen hipotez testleri sonuçları değerlendirildiğinde tüketicinin konut tercihinde eğitim durumu ve cinsiyet değişkenlerine göre anlamlı ilişki bulunmuş ancak satın alma kararı, yaş, medeni durum, meslek ve gelir düzeyi değişsenleri ile anlamlı ilişki bulunmadığı gözlenmiştir. Tüketicinin konut tercihlerinde öncelikli olarak konutun depreme dayanıklı olması, konum, ulaşım, odaların yüzölçümü, doğalgaz bağlantısı ve yalıtım gibi konulara önem verdiği; akıllı ev sistemlerinin konutta varlığına ise diğer kriterler kadar ilgi göstermediği görülmüştür. Çalışma sonunda bu bilgiler ışı̆̆ında yüklenicilere hedef kitlenin belirlenmesi ve pazarlama çalışmaları ile ilgili öneriler sunulmuştur.

Anahtar Kelimeler: Pazarlama, Tüketici, Konut satın alma davranış1, Tüketici konut tercihi

\section{The Effects of the Demographic Characteristics of the Consumers on the House Buying Behavior}

\begin{abstract}
In this study, in order to analyze the consumer behavior in buying houses and the parameters underlying these behaviors, the qualities that consumer considers to be important in the house they buy or intend to buy were determined. In addition, the effects of demographic characteristics of the consumer such as gender, age, marital status, education, income level and occupation on housing preferences were investigated. It has been determined that the majority of the participants in the study consist of individuals with a middle income level who are considering buying a house due to need. When the results of the hypothesis tests were evaluated, it was observed that there was a significant relationship in the consumer's housing preference according to the variables of education and gender, however, there was no significant relationship with the variables of purchasing decision, age, marital status, occupation and income level. Moreover, it has been observed that the consumer primarily attaches importance to issues such as earthquake resistance of the house, location, transportation, surface area of the rooms, natural gas connection and insulation; while the presence of smart home systems in the house does not show as much
\end{abstract}

*Sorumlu yazar (Corresponding author): Gözde TANTEKIN ÇELIK, gtantekin@cu.edu.tr 
interest as other criteria. As a result of the study, in the light of the obtained findings, suggestions were presented to the contractors regarding the determination of the target audience and marketing activities.

Keywords: Marketing, Consumer, Housing buying behavior, Consumer housing preferences

\section{GÍRIŞ}

Her birey yaşamının farklı evrelerinde farklı ihtiyaçlar duymaktadır. Pek çok birey eğitim hayatını tamamladıktan ve bir iş sahibi olduktan sonra otomobil ve konut sahibi olmayı hedeflemektedir. Konut, bireylerin en temel gereksinimlerinden biri olan barınma ihtiyacını karşılayan fiziksel bir mekân olmasının yanı sıra ekonomik, değişim, kullanım ve estetik değerlerin bir bütünü olarak ifade edilebilir. Satın alınan bir konut, bireyin yaşamı boyu kullandığı ve hatta kendi hayatı son bulduktan sonra gelecek nesillere aktarılabilen uzun vadeli tüketim özelliğine sahip bir varlık türüdür [1].

Birçok birey hayatı boyunca bir ya da iki kere konut satın alabilmekte ve satın aldığı konutta uzun yıllar oturmaktadır. Sık değiştirilebilen bir yatırım olmaması sebebiyle tüketiciler konut satın alırken detaylı düşünmekte ve araştırmaktadır. Tüketicinin konut satın alırken pek çok unsurun etkili olduğu yapılan çalışmalarda [2-7] görülmüştür. Tüketicinin demografik özellikleri, psikolojik unsurlar, sosyal ihtiyaçlar gibi pek çok unsur tüketicinin konut satın alma davranışını etkileyebilmektedir [2-8]. Şenyurt çalışmasında tüketicinin konut satın alma davranışını etkileyen 13 faktör belirlemiş ve faktörlerin genelinin demografik özelliklerden; cinsiyet ve medeni durum ile ilişkili olduğunu belirtmiş̧tir [1]. Yapılan farklı çalışmalarda ise gelir düzeyi gibi sosyo-ekonomik unsurların [2] ve tüketicinin yaşam tarzı gibi sosyal unsurların da konut satın alma davranışı üzerinde etkileri olduğu bilinmektedir [3]. Tüketicinin kendini güvende hissetme [4] ve gizlilik-özel alan [5] ihtiyacı da konut tercihini etkileyen psikolojik unsurlar arasında yer almaktadır.

Türkiye'de gerek kentsel dönüşüm gerekse artan nüfus ve gelişen teknoloji sebebiyle büyüyen şehirlerde konut yapım işi ile uğraşan yüklenicilerin hitap ettiği müşteri portföyünü belirleyerek, ihtiyaca uygun tasarımlar yapması ve pazarlama çalışmalarını bu doğrultuda yürütmesi gerekmektedir [2-4]. Literatürde tüketicinin konut tercihlerini etkileyen pek çok çalışma [2-8] bulunmakla beraber bu tercihlerin anlamlı ve az sayıda faktör altında gruplanması ile ilgili fazla çalışmaya [1,6,9-11] rastlanmamıştır. Şenyurt konut satın alma davranışını 13 faktör altında incelemiştir [1]. Kellekci ve Berköz konut ve çevresel kalite memnuniyetini inceledikleri çalışmalarında konutu diş çevresi ile değerlendirmişler ve altı ana boyut belirlemişlerdir [7]. Yalçın ve diğerleri ikamet amaçlı ve yatırım amaçlı konut satın alan tüketicinin satın alma davranışını inceledikleri çalışmalarında her iki örneklem için de üç faktörlü bir yapı elde etmişlerdir [8]. Aktürk ve Tekman konut satın alma kararında etkili olan faktörleri 5 ana faktör altında incelemişlerdir [6]. Güremen ise konut ve yerleşim alanı kullanıc1 algısının memnuniyet ve tercih davranışına etkisi üzerine yaptığı çalışmasında; kullanıcının memnuniyetini 6 faktör altında incelemiştir [9]

Tüketicinin konut tercihlerini etkileyen unsurların faktör yapısının araştırılması ve faktör bazında da incelenmesi ile alıcı değerlendirmeleri ve mülk özellikleri daha iyi analiz edilebilir [12].

$\mathrm{Bu}$ çalışmanın amacı şehirde yaşayan günümüz tüketici grubunun konut satın alma davranışlarının araştırılması, konut tercihlerinde önem verdikleri konuların belirlenmesi ve yaşam tarzları, değerleri ve aile yapıları ile uyumlu ve empatik yanıtlar önerilmesidir [13]. Başarılı bir konut sektörü kurmanın anahtarı, yüklenici firmaların bu sorunları yeterince belirleme becerileridir [14].

Literatürde yapılan çalışmaların geneli tüketicinin konut satın alma davranışını etkileyen dış faktörlere (sosyo-kültürel faktörler, pazarlama faktörleri, durumsal faktörler) ve iç faktörlere (psikolojik faktörler, kişisel faktörler) yoğunlaşmaktadır [2- 
$4,15,16]$. Tüketicinin konut tercihini etkileyen pek çok alt faktör olması zaman zaman tüketicinin bile karar verme sürecini olumsuz etkileyen bir döngüye dönüşebilmektedir. Konut tercihini etkileyen her bir unsurun kendi göreceli önemi olduğundan, konut tercihlerinin çok kriterli karar vermeyi içeren ve tüketicinin demografik özelliklerinden de etkilenebilen bir karar mekanizması bulunmaktadır [17]. $\mathrm{Bu}$ çalışmada tüketicinin tercihlerinde konutun sahip olduğu özellikler (mimari tasarım, malzeme kullanımı, fonksiyonellik vs.) üzerinde de durulmuştur. Ayrıca tüketicinin cinsiyet, yaş, medeni durum, eğitim, gelir düzeyi, meslek gibi demografik özelliklerinin konut tercihlerine etkileri ve değerlendirmeye alınan demografik özelliklerden cinsiyet ve eğitim durumu unsurlarının diğer faktörlere nasıl etkileri olabileceği araştırılmıştır.

Çalışma sonucunda ortaya çıkan sonuçların konut yapım işinde uzmanlaşan inşaat firmalarına arsa seçimi ya da konut niteliğinin saptanması gibi konularda yol gösterici olacağı ayrıca tüketicinin önem verdiği konulara yoğunlaşan bir reklam ve pazarlama stratejisi belirlemeleri açısından da yararlı olacağı düşünülmektedir. Bu nedenle, açıkça tanımlanmış bir stratejinin, bu genişleyen ve dinamik sektördeki tasarımcılara ve yöneticilere çeşitli ve yüksek kaliteli konut programları oluşturmalarında yardımcı olacağı öngörülmektedir [13]. Konut pazarının benzersiz gereksinimlerini karşılamada etkili bir tasarım yapabilmek ve doğru belirlenen hedef kitlenin ihtiyaçlarına nokta atışı yapan bir pazarlama stratejisi uygulamak; kuşkusuz, firmalar için önemli bir rekabet avantajı sağlayacaktır [14].

\section{YÖNTEM}

$\mathrm{Bu}$ çalışmanın amacı tüketicinin konut satın alma davranışını etkileyen konut ile ilgili tercihlerinin belirlenmesidir. Ayrıca çalışma kapsamında tüketicinin demografik özelliklerinin konut ile ilgili tercihlerine olan etkisi de araştırılmıştır. Çalışma kapsamında rastgele seçilmiş tüketicilere uygulanmak üzere iki ana bölümden oluşan bir anket tasarlanmıştır. Anketin ilk bölümünde tüketicinin demografik özellikleri (cinsiyet, yaş, medeni durum, eğitim düzeyi, meslek, gelir düzeyi) ve konut satın alma sebebi (ihtiyaç, yatırım, koşulları iyileştirme) ile ilgili sorular sorulmuş, ikinci bölümünde ise satın aldığ 1 ya da satın almayı düşündüğü konuta ait özellikler ile ilgili sorular sorulmuştur. Anketin ikinci bölümünde yer alan sorular 5'li Likert tipi ölçeğe göre cevaplanmıştır. Çalışma, araştırmacının imkanları doğrultusunda gerçekleştirilmiştir. Anket 2000 kişiden fazla tüketiciye mail yoluyla ulaştırılmış fakat 235 değerlendirmeye uygun geri dönüş yapılmıştır.

Anketin güvenilirliği Cronbach Alpha $(\alpha)$ katsayısı hesaplanarak ölçülmüştür. Verilerin normal dağılıma uygunluğu ise Kolmogrov-Smirnov testi kullanılarak değerlendirilmiştir. Anketin ilk bölümündeki verilerin yüzde ve frekans değerleri hesaplanmıştır. Anketin ikinci bölümünde yer alan sorular normallik varsayımını karşılamadığı için, verilerin değerlendirilmesinde medyan (ortanca) değerleri kullanılmıştır.

Tüketicinin konut satın alma davranışı, konuttaki tercihlerinin ve bu tercihlerin faktör yapısının araştırılmasının amaçlandığı bu çalışmada uygulanan açımlayıcı faktör analizi için sosyal bilimlerde 200 örneklem büyüklüğünün yeterli olduğu bilinmektedir [10,11]. Çalışmadan elde edilen 235 örneklem sayısının çalışma kapsamında yapılan açımlayıcı faktör analizi için yeterli olduğu kabulü ile değerlendirmeler yapılmıştır.

Tüketicinin satın aldığg ya da almayı düşündüğü konut ile ilgili tercihlerinin sorulduğu 19 sorudan oluşan ölçeğe Temel Bileşenler Analizi (Principal Component Analysis - PCA) yöntemi ile açımlayıcı faktör analizi uygulanmış ve sonuçlar paylaşılmıştır. Faktör analizi sonucu ortaya çıkan faktör yapısına bağlı olarak tüketicinin demografik özellikleri ile konut tercihi arasında ilişkinin araştırılması amacıyla Mann-Whitney U ve Kruskal Wallis analizleri kullanılarak Çizelge 1'de verilen hipotezler test edilmiştir. Çalışma kapsamında yapılan analizler MS Excel 2016 ve SPSS 18 paket programları kullanılarak gerçekleştirilmiştir. 
Çizelge 1. Araştırma hipotezleri

\begin{tabular}{|c|l|}
\hline $\begin{array}{c}\text { Hipotez } \\
\text { No }\end{array}$ & \multicolumn{1}{|c|}{ Ho $_{0}$ Hipotezleri } \\
\hline $\mathrm{H}_{01}$ & $\begin{array}{l}\text { Tüketicinin konut tercihi ile satın alma } \\
\text { kararı arasında anlamlı ilişki yoktur. }\end{array}$ \\
\hline $\mathrm{H}_{02}$ & $\begin{array}{l}\text { Tüketicinin konut tercihi ile cinsiyeti } \\
\text { arasında anlamlı ilişki yoktur. }\end{array}$ \\
\hline $\mathrm{H}_{03}$ & $\begin{array}{l}\text { Tüketicinin konut tercihi ile yaşı arasında } \\
\text { anlamlı ilişki yoktur. }\end{array}$ \\
\hline $\mathrm{H}_{04}$ & $\begin{array}{l}\text { Tüketicinin konut tercihi ile medeni } \\
\text { durumu arasında anlamlı ilişki yoktur. }\end{array}$ \\
\hline $\mathrm{H}_{05}$ & $\begin{array}{l}\text { Tüketicinin konut tercihi ile eğitim durumu } \\
\text { arasında anlamlı ilişki yoktur. }\end{array}$ \\
\hline $\mathrm{H}_{06}$ & $\begin{array}{l}\text { Tüketicinin konut tercihi ile mesleği } \\
\text { arasında anlamlı ilişki yoktur. }\end{array}$ \\
\hline $\mathrm{H}_{07}$ & $\begin{array}{l}\text { Tüketicinin konut tercihi ile gelir düzeyi } \\
\text { arasında anlamlı ilişki yoktur. }\end{array}$ \\
\hline
\end{tabular}

\section{ARAŞTIRMA BULGULARI VE TARTIȘMA}

Tüketicinin konut tercihi anketi için hesaplanan Cronbach Alpha değeri 0,954 çıkmıştır. Cronbach Alpha değerinin 0,8'in üzerinde olması kullanılan anketin "yüksek" derecede güvenilir olduğunu göstermektedir [18]. Verilerin normal dağılıma uygunluğunu test etmek amaciyla KolmogrovSmirnov testi uygulanmış ve tüm maddelerin anlamlılık düzeylerinin \%5'ten küçük olduğu ve normal dağılıma uymadığı görülmüştür. Tüketicinin konut tercihi anketi normal dağılıma uymadığı için anket sonuçları medyan değerleri verilerek sunulmuştur.

Katılımcılara ait demografik bilgiler Çizelge 2'de verilmiştir. Ankete \%45,96's1 erkek, \%54,04'ü kadın olmak üzere toplam 235 kişi katılmıştır. Katılımcıların genelini 40 yaş altı bireyler oluşturmaktadır. Ankete katılanların \%57,45'i evli, \%42,55'i ise bekâr bireylerden oluşmaktadır. Katılımcıların genelinin lisansüstü düzeyde eğitim seviyesine sahip olduğu Çizelge 2'de görülmektedir. Katılımcıların \%49,36'sının devlet memuru ve \%40,00'nın özel sektör çalışanı olduğu görülmüştür. Çalışmaya katılanların genelini $\% 46,81$ 'lik bir oranla 5.501-8.500 TL arası geliri olan bireyler oluşturmaktadır. Bireylerin \%5,53'ü çalışmanın yapıldığ 1 dönemde asgari ücret olan 2.020,90 TL ve alt1 gelire sahipken, \%11,06's1
2.021-3.500TL aras1, \%17,87'si 3.501-5.500 TL aras1, \%11,49'u 8.501-12.500 TL aras1, \%5,53'ü 12.501-20.000 TL aras1 ve \%1,70'i 20.001 TL ve üzeri gelire sahiptir. Ankete katılanların genelinin orta gelir grubunda ve lisansüstü eğitime sahip olduğu görülmektedir.

Tüketicilere konut satın alma sebepleri sorulduğunda, genelinin ihtiyaç sebebi ile konut satın aldığı, koşulları iyileştirme ya da yatırım amaçlı konut satın alanların ise daha az olduğu görülmüştür (Çizelge 3).

Tüketicinin konut satın alırken tercihleri ile ilgili sonuçlar Çizelge 4'te verilmiştir. Tüketicinin konut satın alırken; konutun depreme dayanıklı oluşuna, konumuna, ulaşım olanaklarına, yüzölçümüne, doğalgaz bağlantısı ve yalıtım konularına çok önem verdiği görülmüştür. Akıllı ev sisteminin ise en son sırada yer aldığı ve tüketiciler tarafından çok önemsenmediği görülmüştür.

Tüketicinin konut tercihlerini belirlemek amacıyla rastgele seçilmiş 235 bireye bir anket çalışması uygulanmıştır. Tüketicilerin genelini 26-40 yaş arası, lisansüstü mezunu ve 5501 TL üstü geliri olan bireylerin oluşturduğu görülmüştür. Katılımcıların genelinin ihtiyaçtan dolayı ev satın aldığı ya da almayı düşündüğü belirlenmiştir. Çalışma sonucunda tüketicinin satın aldığı konut ile ilgili olarak; depreme dayanıklı oluşuna, konumuna, ulaşım olanaklarına, yüzölçümüne, doğalgaz bağlantısı ve yalıtım konularına çok önem verdiği görülmüştür. Ülkede yaşanan depremler sonrası "depreme dayanıklı konut üretimi” firmalar tarafından da reklamlarında vurgulanan bir özellik olarak ön plana çıkmaktadır. Yaşanan doğal afetlerin tüketicinin tercihlerinde öne çıkması doğal karşılanmaktadır [19]. Bu durum incelendiğinde konum, ulaşım gibi unsurlar konutun lokasyonu ile alakalı konuları oluştururken, sağlam olması ve yeterli büyüklüğe sahip olması gibi unsurlar konutun sabit yani tüketici tarafından değiştirilemez özelliklerini kapsamaktadır. Tüketicinin konut satın alırken işyerine yakınlık ya da şehir merkezine yakınlık gibi konulara önem verdiği ayrıca çocuk sahibi olan bireylerin okula yakınlık unsurundan dolayı konutun konumuna önem verdikleri görülmüştür [20]. Diğer unsurlar olan; doğalgaz 
bağlantısı ve yalıtım ise evde tadilat gerektiren ve masraflı sayılabilecek unsurlardır. Daha az önem verilen mutfağın ve banyonun tasarımı, estetik değerler gibi unsurlar ise tüketicinin tadilat ile değiştirebileceği unsurlardır. Bunların yanı sıra; balkon sayısı, kat yüksekliği, cephesi, site içerisinde oluşu gibi unsurlarda tüketici için daha az öneme sahiptir. Akıllı ev sisteminin ise en son sirada yer aldığı ve tüketiciler tarafından çok da önemsenmediği görülmüştür. Örneklemin genelini orta gelir grubu oluşturmaktadır ve genelde akıllı ev sistemleri üst segmente hitap eden evlerde daha çok kullanılmaktadır. Akıllı ev sisteminin orta gelir grubu tarafından önemli bir ihtiyaç olarak algılanmadığı görülmüştür.

Çizelge 2. Katılımcıların demografik özellikleri

\begin{tabular}{|c|c|c|}
\hline (2) & $\mathbf{n}$ & $\%$ \\
\hline \multicolumn{3}{|c|}{ Cinsiyet } \\
\hline Erkek & 108 & 45,96 \\
\hline Kadın & 127 & 54,04 \\
\hline Toplam & 235 & 100 \\
\hline \multicolumn{3}{|c|}{ Yaş } \\
\hline 25 yaş ve altı & 22 & 9,36 \\
\hline $26-30$ yaş & 83 & 35,32 \\
\hline $31-35$ yaş & 42 & 17,87 \\
\hline $36-40$ yaș & 42 & 17,87 \\
\hline $41-45$ yaş & 24 & 10,21 \\
\hline 46 yaş ve üzeri & 22 & 9,36 \\
\hline Toplam & 235 & 100 \\
\hline \multicolumn{3}{|c|}{ Medeni Hal } \\
\hline Bekar & 100 & 42,55 \\
\hline Evli & 135 & 57,45 \\
\hline Toplam & 235 & 100 \\
\hline \multicolumn{3}{|c|}{ Eğitim Durumu } \\
\hline İlköğretim & 0 & 0 \\
\hline Lise & 3 & 1,28 \\
\hline Üniversite & 67 & 28,51 \\
\hline Lisans Üstü & 165 & 70,21 \\
\hline Toplam & 235 & 100 \\
\hline \multicolumn{3}{|c|}{ Meslek } \\
\hline Öğrenci & 11 & 4,68 \\
\hline Devlet Memuru & 116 & 49,36 \\
\hline Özel Sektör & 94 & 40,00 \\
\hline Serbest Meslek & 6 & 2,55 \\
\hline Emekli & 3 & 1,28 \\
\hline İşsiz & 5 & 2,13 \\
\hline Toplam & 235 & 100 \\
\hline \multicolumn{3}{|c|}{ Gelir Düzeyi (TL) } \\
\hline $2.020,90 \mathrm{TL}$ ve alt1 & 13 & 5,53 \\
\hline $2.021-3.500 \mathrm{TL}$ aras 1 & 26 & 11,06 \\
\hline $3.501-5.500 \mathrm{TL}$ aras 1 & 42 & 17,87 \\
\hline $5.501-8.500 \mathrm{TL}$ aras 1 & 110 & 46,81 \\
\hline $8.501-12.500$ TL aras1 & 27 & 11,49 \\
\hline $12.501-20.000 \mathrm{TL}$ aras1 & 13 & 5,53 \\
\hline 20.001 TL ve üzeri & 4 & 1,70 \\
\hline Toplam & 235 & 100 \\
\hline
\end{tabular}

Tüketicinin satın aldığı ya da almayı düşündüğü konutun sahip olması gereken özelliklerinin ölçüldüğü 19 sorudan oluşan ölçeğe Temel Bileşenler Analizi (Principal Component AnalysisPCA) yöntemi ile açımlayıcı faktör analizi uygulanmıştır. Tüketicilerin konut tercihleri ölçeğine ait 19 soru bir faktör altında toplanmıştır. Çizelge 5' de tüketicinin konut tercihleri ölçeğine ait açımlayıcı faktör analizi sonuçları verilmiştir. Madde yükleri 0,839 ile 0,587 arasında değişmektedir. Bir faktörün toplam varyansa yaptığ 1 katkı \%56,169'dur. Tüketicinin satın aldığ1 ya da almayı düşündüğü konutun sahip olması gereken özellikler ölçeğinin tek faktörlü yapısı "tüketicinin konut tercihi" faktörü olarak isimlendirilmiştir. 
Çizelge 3. Tüketicilerin konut satın alma sebepleri

\begin{tabular}{|l|c|c|}
\hline Konut satın alma davranışı altında yatan sebepler & $\mathbf{n}$ & $\mathbf{\%}$ \\
\hline İhtiyaç & 129 & 54,89 \\
\hline Koşulları iyileştirme (Daha büyük veya daha yeni bir ev gerekliliğinin oluşması vb.) & 50 & 21,28 \\
\hline Yatırım & 49 & 20,85 \\
\hline Diğer & 7 & 2,98 \\
\hline Toplam & 235 & 100 \\
\hline
\end{tabular}

Çizelge 4. Tüketicinin önem verdiği konut özellikleri

\begin{tabular}{|c|l|c|}
\hline \multicolumn{2}{|l|}{ Maddeler } & Medyan (Ortanca) \\
\hline $\mathbf{1}$ & Deprem yönetmeliğine uygun oluşu & 5 \\
\hline $\mathbf{2}$ & Konumu & 5 \\
\hline $\mathbf{3}$ & Ulaşım olanakları & 5 \\
\hline $\mathbf{4}$ & Odaların yüzölçümü & 5 \\
\hline $\mathbf{5}$ & Doğalgaz tesisatı/bağlantısı & 5 \\
\hline $\mathbf{6}$ & Yalıtımı & 5 \\
\hline $\mathbf{7}$ & Mutfağının tasarımı (modern dizaynı, konsept dizaynı, yüzölçümü vb.) & 4 \\
\hline $\mathbf{8}$ & İkinci el konut satın alırken, yenilenmiş ve iyileştirilmiş oluşunu önemserim. & 4 \\
\hline $\mathbf{9}$ & Cephesi (Güneş alma durumu) & 4 \\
\hline $\mathbf{1 0}$ & Banyosunun tasarımı (küvet, jakuzi, duşa kabin, ebeveyn banyosu vb.) & 4 \\
\hline $\mathbf{1 1}$ & İç mekan tasarımı - Estetik değerler (Malzeme ve renk kullanımı vs.) & 4 \\
\hline $\mathbf{1 2}$ & Odaların birbiriyle olan ilişkisi (fonksiyonellik) & 4 \\
\hline $\mathbf{1 3}$ & Dairenin bulunduğu kat yüksekliği & 4 \\
\hline $\mathbf{1 4}$ & Dolap sayısı, depolama imkan1 & 4 \\
\hline $\mathbf{1 5}$ & Ek imkânlar (Otopark, güvenlik, çocuk park1, spor salonu, havuz vb.) & 4 \\
\hline $\mathbf{1 6}$ & Manzaralı oluşu (Deniz manzarası, şehir manzarası vb.) & 4 \\
\hline $\mathbf{1 7}$ & Balkon sayısı & 4 \\
\hline $\mathbf{1 8}$ & Site içerisinde olması & 4 \\
\hline $\mathbf{1 9}$ & Akillı ev sistemlerine sahip oluşu & 3 \\
\hline
\end{tabular}

Çizelge 5. Tüketicinin konut tercihi anketi faktör yapısı

\begin{tabular}{|c|c|}
\hline Anket sorulari & Tüketicinin konut tercihi anketinin faktör yükleri \\
\hline 9 & 0,839 \\
\hline 10 & 0,826 \\
\hline 5 & 0,810 \\
\hline 1 & 0,809 \\
\hline 13 & 0,799 \\
\hline 17 & 0,791 \\
\hline 15 & 0,778 \\
\hline 4 & 0,770 \\
\hline 14 & 0,762 \\
\hline 11 & 0,754 \\
\hline 8 & 0,740 \\
\hline 12 & 0,736 \\
\hline 3 & 0,729 \\
\hline 7 & 0,727 \\
\hline 19 & 0,702 \\
\hline 16 & 0,697 \\
\hline 2 & 0,669 \\
\hline 18 & 0,666 \\
\hline 6 & 0,587 \\
\hline KMO & \\
\hline Barlett Kürellik Testi sig. $=0,000$ & \\
\hline & \\
\hline
\end{tabular}


Tüketicinin demografik özelliklerinin konut tercihlerindeki etkisini araştırmak amacıyla oluşturulan hipotezler Mann-Whitney $U$ ve Kruskall Wallis analizleri ile yapılmış ve sonuçlar Çizelge 6'da paylaşılmıştır. Hipotez testleri sonucunda anlamlılık değeri \%0,05'ten küçük çıkan hipotezler reddedilmiştir. Yapılan hipotez testleri sonucunda tüketicinin konut tercihinde eğitim durumu ve cinsiyete göre anlamlı ilişki bulunmuş; satın alma kararı, yaş, medeni durum, meslek ve gelir düzeyi ile anlamlı ilişki bulunmadığg gözlemlenmiştir.

Cinsiyet ve eğitim düzeyine göre bireylerin konuta ait hangi tercihlerinde farklılık olduğunun detaylı analiz edilmesi için tüketicinin konut tercihi anketinde bulunan her bir madde için MannWhitney U (cinsiyet) ve Kruskall Wallis (eğitim düzeyi) analizi uygulanmıştır. "Tüketicinin konuta yönelik tercihlerinde (19 madde için) cinsiyete göre anlamlı farklılık yoktur" hipotezine ait sonuçlar Çizelge 7'de özetlenmiştir. "Tüketicinin konuta yönelik tercihlerinde (19 madde için) eğitim düzeyine göre anlamlı farklılık yoktur" hipotezine ait sonuçlar ise Çizelge 8'de özetlenmiştir.

Yapılan hipotez testleri sonucunda tüketicinin ev satın alma sebebi ile konut tercihleri arasında anlamlı bir ilișki bulunmamıştır. Tüketicinin demografik özelliklerinden; cinsiyet ve eğitim düzeyi ile konut tercihleri arasında anlamlı farklılık bulunmuştur. Kadın katılımcıların; mutfak ve banyonun tasarımı, ikinci el konutlarda konutun yenilenmiş olması, yüz ölçümü, kat yüksekliği, fonksiyonellik, doğalgaz bağlantısının varlığı, dolap/depo imkânı, balkon sayısı, konum, ulaşım, cephe ve site içerisinde oluşu konularına erkek katılımcılardan daha fazla önem verdiği gözlenmiştir [21]. Konut satın alırken kadınların konutu ve imkânlarını çok daha aktif kullandığı ve bu sebeple erkeklere göre çok daha detaylı düşündüğü görülmektedir.

Eğitim düzeyine göre incelendiğinde; üniversite ve lisansüstü mezunlarının lise mezunlarına göre konutun; deprem yönetmeliğine uygun oluşu, iç mekân tasarımına, yüz ölçümüne, akıllı ev sistemi, kat yüksekliği, yalıtım, dolap/depo imkânı, balkon sayısı, cephesi, site içi imkânlar, ek imkânlar ve ikinci el konutun yenilenmiş olması gibi konulara daha fazla önem verdiği görülmüştür [22]. Lisans ve lisansüstü mezunlarının depreme dayanıklılık konusunda daha titiz davranmaları daha bilinçli olmalarına bağlanabilir. Genel olarak, lisans ve lisansüstü mezunlarının gelir düzeyi lise mezunlarından daha yüksek olmaktadır. Sonuçlar incelendiğinde; lisans ve lisansüstü mezunlarının her evin taşıması gereken ana ve optimum özelliklere (fonksiyonellik, doğalgaz, konum, ulaşım, manzara, mutfak ve banyonun tasarımı vs.) ek olarak iç mekan tasarımı, yalıtım, dolap/depo imkanı, balkon sayısı, cephe, site içi olma durumu ve ek imkanlar gibi farklı özellikleri lise mezunlarına göre daha fazla önemsedikleri görülmüştür.

Çizelge 6. Tüketicinin konut tercihi ile ilgili genel hipotezler

\begin{tabular}{|c|l|c|c|}
\hline $\begin{array}{c}\text { Hipotez } \\
\text { no }\end{array}$ & $\mathbf{H}_{\mathbf{0}}$ Hipotezleri & Anlamlılık & Kabul/Red \\
\hline $\mathrm{H}_{01}$ & $\begin{array}{l}\text { Tüketicinin konut tercihi ile satın alma kararı arasında anlamlı ilişki } \\
\text { yoktur. }\end{array}$ & 0,329 & \\
\hline $\mathrm{H}_{02}$ & Tüketicinin konut tercihinde cinsiyete göre anlamlı farklılık yoktur. & 0,000 & Red \\
\hline $\mathrm{H}_{03}$ & Tüketicinin konut tercihinde yaşa göre anlamlı farklılık yoktur. & 0,144 & \\
\hline $\mathrm{H}_{04}$ & $\begin{array}{l}\text { Tüketicinin konut tercihinde medeni durumuna göre anlamlı farklılık } \\
\text { yoktur. }\end{array}$ & 0,136 & \\
\hline $\mathrm{H}_{05}$ & $\begin{array}{l}\text { Tüketicinin konut tercihinde eğitim durumuna göre anlamlı farklılık } \\
\text { yoktur. }\end{array}$ & 0,026 & Red \\
\hline $\mathrm{H}_{06}$ & Tüketicinin konut tercihinde mesleğine göre anlamlı farklılık yoktur. & 0,057 & \\
\hline $\mathrm{H}_{07}$ & $\begin{array}{l}\text { Tüketicinin konut tercihinde gelir düzeyine göre anlamlı farklılık } \\
\text { yoktur. }\end{array}$ & 0,422 & \\
\hline
\end{tabular}


Çizelge 7. Tüketicinin konut tercihi ve cinsiyeti ile ilgili yapılan hipotezler

\begin{tabular}{|c|c|c|c|c|}
\hline Hipotez no & $\mathrm{H}_{0}$ Hipotezleri & Anlamlılık & Kabul/Red & Açıklama \\
\hline $\mathrm{H}_{08}$ & $\begin{array}{l}\text { Tüketicinin "Deprem yönetmeliğine uygun oluşu" } \\
\text { tercihinde cinsiyete göre farklılık yoktur. }\end{array}$ & 0,230 & & \\
\hline $\mathrm{H}_{09}$ & $\begin{array}{l}\text { Tüketicinin “Konum” tercihinde cinsiyete göre } \\
\text { farkl1lık yoktur. }\end{array}$ & 0,001 & Red & Kadın $>$ Erkek \\
\hline $\mathrm{H}_{010}$ & $\begin{array}{l}\text { Tüketicinin "Ulaşım olanakları" tercihinde } \\
\text { cinsiyete göre farklılık yoktur. }\end{array}$ & 0,006 & Red & Kadın $>$ Erkek \\
\hline $\mathrm{H}_{011}$ & $\begin{array}{l}\text { Tüketicinin "Odaların yüzölçümü" tercihinde } \\
\text { cinsiyete göre farklılık yoktur. }\end{array}$ & 0,017 & Red & Kadın $>$ Erkek \\
\hline $\mathrm{H}_{012}$ & $\begin{array}{l}\text { Tüketicinin "Doğalgaz tesisat1/bağlantısı" } \\
\text { tercihinde cinsiyete göre farkl1lık yoktur. }\end{array}$ & 0,000 & Red & Kadın $>$ Erkek \\
\hline $\mathrm{H}_{013}$ & $\begin{array}{l}\text { Tüketicinin "Yalıtım" tercihinde cinsiyete göre } \\
\text { farklılık yoktur. }\end{array}$ & 0,162 & & \\
\hline $\mathrm{H}_{014}$ & $\begin{array}{l}\text { Tüketicinin "Mutfağının tasarımı (modern dizaynı, } \\
\text { konsept dizaynı, yüzölçümü vb.)" tercihinde } \\
\text { cinsiyete göre farklılık yoktur. }\end{array}$ & 0,000 & Red & Kadın $>$ Erkek \\
\hline $\mathrm{H}_{015}$ & $\begin{array}{l}\text { Tüketicinin “İkinci el konut satın alırken, } \\
\text { yenilenmiş ve iyileştirilmiş oluşunu önemserim.” } \\
\text { tercihinde cinsiyete göre farklılık yoktur. }\end{array}$ & 0,002 & Red & Kadın $>$ Erkek \\
\hline $\mathrm{H}_{016}$ & $\begin{array}{l}\text { Tüketicinin "Cephe (Güneş alma durumu)" } \\
\text { tercihinde cinsiyete göre farklılık yoktur. }\end{array}$ & 0,000 & Red & Kadın $>$ Erkek \\
\hline $\mathrm{H}_{017}$ & $\begin{array}{l}\text { Tüketicinin "Banyosunun tasarımı (küvet, jakuzi, } \\
\text { duşa kabin, ebeveyn banyosu vb.)" tercihinde } \\
\text { cinsiyete göre farklılık yoktur. }\end{array}$ & 0,001 & Red & Kadın>Erkek \\
\hline $\mathrm{H}_{018}$ & $\begin{array}{l}\text { Tüketicinin “İç mekan tasarımı - Estetik değerler } \\
\text { (Malzeme ve renk kullanımı vs.)" tercihinde } \\
\text { cinsiyete göre farklılık yoktur. }\end{array}$ & 0,059 & & \\
\hline $\mathrm{H}_{019}$ & $\begin{array}{l}\text { Tüketicinin "Odaların birbiriyle olan ilişkisi } \\
\text { (fonksiyonellik)" tercihinde cinsiyete göre farklılık } \\
\text { yoktur. }\end{array}$ & 0,018 & Red & Kadın $>$ Erkek \\
\hline $\mathrm{H}_{020}$ & $\begin{array}{l}\text { Tüketicinin "Dairenin bulunduğu kat yüksekliği”" } \\
\text { tercihinde cinsiyete göre farklılık yoktur. }\end{array}$ & 0,016 & Red & Kadın $>$ Erkek \\
\hline $\mathrm{H}_{021}$ & $\begin{array}{l}\text { Tüketicinin "Dolap sayısı, depolama imkanı" } \\
\text { tercihinde cinsiyete göre farklılık yoktur. }\end{array}$ & 0,000 & Red & Kadın $>$ Erkek \\
\hline $\mathrm{H}_{022}$ & $\begin{array}{l}\text { Tüketicinin "Ek imkânlar (Otopark, güvenlik, } \\
\text { çocuk parkı, spor salonu, havuz vb.)" tercihinde } \\
\text { cinsiyete göre farklılık yoktur. }\end{array}$ & 0,071 & & \\
\hline $\mathrm{H}_{023}$ & $\begin{array}{l}\text { Tüketicinin "Manzaralı oluşu (Deniz manzarası, } \\
\text { şehir manzarası vb.)” tercihinde cinsiyete göre } \\
\text { farklılık yoktur. }\end{array}$ & 0,095 & & \\
\hline $\mathrm{H}_{024}$ & $\begin{array}{l}\text { Tüketicinin "Balkon sayısı" tercihinde cinsiyete } \\
\text { göre farklılık yoktur. }\end{array}$ & 0,038 & Red & Kadın $>$ Erkek \\
\hline $\mathrm{H}_{025}$ & $\begin{array}{l}\text { Tüketicinin "Site içerisinde olması" tercihinde } \\
\text { cinsiyete göre farklılık yoktur. }\end{array}$ & 0,033 & Red & Kadın $>$ Erkek \\
\hline $\mathrm{H}_{026}$ & $\begin{array}{l}\text { Tüketicinin "Akıllı ev sistemlerine sahip oluşu" } \\
\text { tercihinde cinsiyete göre farklılık yoktur. }\end{array}$ & 0,052 & & \\
\hline
\end{tabular}


Çizelge 8. Tüketicinin konut tercihi ve eğitim düzeyi ile ilgili yapılan hipotezler

\begin{tabular}{|c|c|c|c|c|}
\hline Hipotez no & 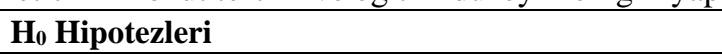 & Anlamlılık & Kabul/Red & Açıklama* \\
\hline $\mathrm{H}_{027}$ & $\begin{array}{l}\text { Tüketicinin "Deprem yönetmeliğine uygun oluşu" } \\
\text { tercihinde eğitim düzeyine göre farklılık yoktur. }\end{array}$ & $\mathbf{0 , 0 0 3}$ & Red & $l \ddot{u}>\ddot{u}>l i$ \\
\hline $\mathrm{H}_{028}$ & $\begin{array}{l}\text { Tüketicinin “Konum” tercihinde eğitim düzeyine } \\
\text { göre farklılık yoktur. }\end{array}$ & 0,131 & & \\
\hline $\mathrm{H}_{029}$ & $\begin{array}{l}\text { Tüketicinin "Ulaşım olanakları" tercihinde eğitim } \\
\text { düzeyine göre farklılık yoktur. }\end{array}$ & 0,186 & & \\
\hline $\mathrm{H}_{030}$ & $\begin{array}{l}\text { Tüketicinin “Odaların yüzölçümü" tercihinde eğitim } \\
\text { düzeyine göre farklıllk yoktur. }\end{array}$ & $\mathbf{0 , 0 1 4}$ & Red & $l \ddot{u}>\ddot{u}>l i$ \\
\hline $\mathrm{H}_{031}$ & $\begin{array}{l}\text { Tüketicinin "Doğalgaz tesisatı/bağlantısı" tercihinde } \\
\text { eğitim düzeyine göre farklılık yoktur. }\end{array}$ & 0,100 & & \\
\hline $\mathrm{H}_{032}$ & $\begin{array}{l}\text { Tüketicinin "Yalıtım” tercihinde eğitim düzeyine } \\
\text { göre farklılık yoktur. }\end{array}$ & 0,005 & Red & $l \ddot{u}>\ddot{u}>l i$ \\
\hline $\mathrm{H}_{033}$ & $\begin{array}{l}\text { Tüketicinin "Mutfağının tasarımı (modern dizaynı, } \\
\text { konsept dizaynı, yüzölçümü vb.)" tercihinde eğitim } \\
\text { düzeyine göre farklılık yoktur. }\end{array}$ & 0,230 & & \\
\hline $\mathrm{H}_{034}$ & $\begin{array}{l}\text { Tüketicinin “İkinci el konut satın alırken, yenilenmiş } \\
\text { ve iyileştirilmiş oluşunu önemserim.” tercihinde } \\
\text { eğitim düzeyine göre farklılık yoktur. }\end{array}$ & $\mathbf{0 , 0 3 4}$ & Red & $\ddot{\mathrm{u}}>\mathrm{lü}>\mathrm{li}$ \\
\hline $\mathrm{H}_{035}$ & $\begin{array}{l}\text { Tüketicinin "Cephe (Güneş alma durumu)" } \\
\text { tercihinde eğitim düzeyine göre farklılık yoktur. }\end{array}$ & $\mathbf{0 , 0 2 5}$ & Red & lü> $\ddot{\mathrm{u}}>\mathrm{li}$ \\
\hline $\mathrm{H}_{036}$ & $\begin{array}{l}\text { Tüketicinin "Banyosunun tasarımı (küvet, jakuzi, } \\
\text { duşa kabin, ebeveyn banyosu vb.)" tercihinde eğitim } \\
\text { düzeyine göre farklılık yoktur. }\end{array}$ & 0,071 & & \\
\hline $\mathrm{H}_{037}$ & $\begin{array}{l}\text { Tüketicinin "İç mekan tasarımı-Estetik değerler } \\
\text { (Malzeme ve renk kullanımı vs.)" tercihinde eğitim } \\
\text { düzeyine göre farklılık yoktur. }\end{array}$ & $\mathbf{0 , 0 1 9}$ & Red & $\ddot{\mathrm{u}}>\mathrm{lü}>\mathrm{li}$ \\
\hline $\mathrm{H}_{038}$ & $\begin{array}{l}\text { Tüketicinin “Odaların birbiriyle olan ilişkisi } \\
\text { (fonksiyonellik)” tercihinde eğitim düzeyine göre } \\
\text { farklılık yoktur. }\end{array}$ & 0,284 & & \\
\hline $\mathrm{H}_{039}$ & $\begin{array}{l}\text { Tüketicinin "Dairenin bulunduğu kat yüksekliği" } \\
\text { tercihinde eğitim düzeyine göre farklılık yoktur. }\end{array}$ & 0,013 & Red & $l \ddot{u}>\ddot{u}>l i$ \\
\hline $\mathrm{H}_{040}$ & $\begin{array}{l}\text { Tüketicinin "Dolap sayısı, depolama imkânı" } \\
\text { tercihinde eğitim düzeyine göre farklılık yoktur. }\end{array}$ & 0,034 & Red & $l \ddot{u}>\ddot{\mathrm{u}}>\mathrm{li}$ \\
\hline $\mathrm{H}_{041}$ & $\begin{array}{l}\text { Tüketicinin "Ek imkânlar (Otopark, güvenlik, çocuk } \\
\text { parkı, spor salonu, havuz vb.)" tercihinde eğitim } \\
\text { düzeyine göre farklılık yoktur. }\end{array}$ & 0,025 & Red & $l \ddot{u}>\ddot{u}>l i$ \\
\hline $\mathrm{H}_{042}$ & $\begin{array}{l}\text { Tüketicinin "Manzaralı oluşu (Deniz manzarası, } \\
\text { şehir manzarası vb.)" tercihinde eğitim düzeyine } \\
\text { göre farklılık yoktur. }\end{array}$ & 0,097 & & \\
\hline $\mathrm{H}_{043}$ & $\begin{array}{l}\text { Tüketicinin "Balkon sayısı" tercihinde eğitim } \\
\text { düzeyine göre farklılık yoktur. }\end{array}$ & 0,021 & Red & $l \ddot{u}>\ddot{u}>l i$ \\
\hline $\mathrm{H}_{044}$ & $\begin{array}{l}\text { Tüketicinin "Site içerisinde olması" tercihinde } \\
\text { eğitim düzeyine göre farklılık yoktur. }\end{array}$ & 0,017 & Red & $l \ddot{u}>\ddot{u}>l i$ \\
\hline $\mathrm{H}_{045}$ & $\begin{array}{l}\text { Tüketicinin "Akıllı ev sistemlerine sahip oluşu" } \\
\text { tercihinde eğitim düzeyine göre farklılık yoktur. }\end{array}$ & 0,012 & Red & $\ddot{\mathrm{u}}>\mathrm{lü}>\mathrm{li}$ \\
\hline
\end{tabular}


Tüketicinin konut ile ilgili tercihlerinin ve bu tercihlerin önem seviyelerinin araştırıldığı bu çalışmada ilk olarak tüketicinin konut satın alma davranışı altında yatan parametrelere bakılmış ve büyük bir çoğunluğun ihtiyaç dolayısıyla konut satın aldığı görülmüştür. Bu sonuca paralel bir şekilde Moral (2018)' da çalışmasında katılımcıların $\% 62,2$ oranında oturum amaçlı konut satın almayı planladıkları sonucuna ulaşmıştır [7,23]. Tüketicilerin konutta önem verdiği özellikler sorulduğunda ise; konutun depreme dayanıklı oluşu, konumu, ulaşım olanakları, yüzölçümü, doğalgaz bağlantısı ve yalıtım gibi özelliklerin öne çıktığı görülmüştür. Karagöz ve diğerleri (2015) çalışmalarında bu sonuçları destekler nitelikte bulgulara ulaşmışlardır. Katılımcıların büyük bir kısmı merkezde bir konutu tercih edeceklerini belirtirken, merkeze yakın konut tercih edenlerinde oranı merkeze uzak tercih edenlerden daha fazladır. Özellikle büyük şehirlerde artan trafik sorunu sebebiyle uzayan ulaşım zamanları sebebiyle bireylerin konut alırken şehirdeki konumuna ve ulaşım imkanlarına önem vermesi kaçınılmazdır. Tosun ve Fırat (2012) ise yaptıkları çalışmada tüketicilere konut satın alma kararında önem verdikleri dışsal faktörleri sormuşlar ve başlıca önem verilen dış faktörlerin sırasıyla; fiyat, güvenlik ve depreme dayanıklılık olduğunu tespit etmişlerdir. Aynı çalışmada katılımcılara konutun içi ile ilgili önem verdikleri konular sorulmuş ve sırasıyla; geniş mutfak, geniş salon ve manzara konularının öne çıktığı tespit edilmiştir. Yapılan bu çalışmada, bireylerin konut satın alırken önem verdiği konuların; konutun konumu, mimari tasarım ve özellikleri, yüzölçümü, sosyal imkânlar, depreme dayanıklılık, güvenlik ve ısınma tipi konuları etrafında toplandığ 1 ve bireyin bu konularda seçici davrandığı belirlenmiştir. Yine benzer sonuçların elde edildiği bir çalışmada Yavuz ve Çemrek (2013) ise katılımciların konut tercihlerinde sirasıyla; konutun bulunduğu kat, konutun metrekaresi (yüzölçümü), konutun site içerisinde yer alması, otopark bulunması, 1sınma tipi ve merkeze olan konumu değişkenlerinin önemsendiğini belirlemişlerdir. Bunlara ek olarak $\mathrm{Su}$ (2016) çalışmasında katılımcılar tarafından sirasıyla; konutun konumu, kredi ödeme ve fiyat1, konutun büyüklüğü, mimari özellikleri, gelecekteki gelir etkisi ve reklamın konut satın alırken tercih sebebi olduğunu ve en çok önemsenen ölçütlerin de sırasıyla; aylık gelir, konut fiyatı, konutun dayanıklılığı, malzeme ve işçilik kalitesi, şehir merkezine yakınlık, düşük faizli, uzun vadeli kredi imkânları ve ödeme koşulları ile yaşam tarzı olduğunu saptamıştır [7,15,1,24,19]. Bu bağlamda firmaların bu özellikleri hedef kitlenin beklentisi sınırları içerisinde konutta bulundurup, öne çıkarmaları gerekmektedir [7].

$\mathrm{Bu}$ çalışmada kurgulanan hipotez testleri sonuçları ile de tüketicinin konut tercihinin eğitim durumu ve cinsiyete ilişkilendirilebildiği; satın alma kararı, yaş, medeni durum, meslek ve gelir düzeyi ile ilişkilendirilemediği gözlemlenmiştir. Benzer biçimde Atabeyli ve Keleş (2020)'de çalışmalarında katılımcıların yaşı, medeni durumu, meslek ve çocuk sayısı gibi demografik belirleyicilerin konut tercihi üzerinde oldukça önemsiz ve hatta bazı durumlarda negatif etkisinin söz konusu olduğunu belirlemişlerdir [25].

Çalışmada konuta ait özelliklere kadın tüketicilerin erkeklerden daha fazla önem verdiği de belirlenmiştir. Atabeyli ve Keleş'in (2020) çalışmalarında ise elde etikleri bulguların bu çalışmayla benzerlik göstermediği görülmüştür. Erkek ve kadın bireyler ile gerçekleştirilen bu çalışmada içsel gizil değişkenler olan Demografik ve Ekonomik Koşullar, Birincil İhtiyaçlara Erişim, İkincil İhtiyaçlara Erişim, Sosyal Çevre ve Komşuluk, İç Mekân Kullanımı ve Dış Mekân Kullanımı faktörlerinin kadın ve erkek bireylerin her ikisinin de Konut Tercihi dişsal gizil değişkeni üzerinde pozitif yönde önemli etkiye sahip olduğu tespit edilmiştir. Bu içsel gizil değişkenler baz alındığında konut tercihleri kadın ve erkek tüketicilerde ufak farklılıklara rağmen aynı etkenler üzerinde şekillenmektedir [25]. Memiş (2018) çalışmasında konutun iç özellikleri açısından kadın ve erkek bireyler arasında farklılıklar söz konusu olduğunu ve bu farklılıkların kadınlardan kaynaklandığı belirlemiştir. Dolayısıyla kadınların tercih edilecek konutun iç özelliklerine bakarak karar verdikleri söylenebilir [26].

Çalışmada ayrıca katılımcıların eğitim düzeylerinin konut tercihlerine etki ettiği sonucuna da ulaşılmıştır. Zorlu ve Sağsöz’ün (2010) müstakil 
konut sitelerinde kullanıcı tercihlerini belirlemeye yönelik çalışmaları sonucu elde ettikleri bulguların bu çalışmayla paralellik göstermediği görülmüştür. Konutta oturulan süre, gelir düzeyi, aile büyüklüğü ve yine konutun kullanımında en etkin kişi olan kadın bireyin eğitim durumu, yaş ve mesleğinin konutta yapılan değişikliklerin türü ve hedeflenen özellikler arasında doğrudan bir ilişki bulunamamıştır [27]. Tremblay ve Dillman (1983) ise çalışmalarında bu çalışma sonuçlarına benzer biçimde katılımcıların eğitim düzeylerinin konut tercihlerinde etkili bir faktör olduğunu, eğitim düzeyi yüksek olan kişilerin konut tercihlerinde uluslararası yönelim ve gelişmelere daha eğilimli olduklarını saptamıştır [26,28].

Öte yandan bir yatırım veya ihtiyaç olarak konutun, çoğu insanın ömründe ya hiç ya da bir kez sahip olabileceği bir yatırım olması durumu dikkate alındığında, bireylerin bu konuya titizlikle yaklaşarak isabetli kararlar verme istekleri kaçınılmaz olmaktadır [7]. Satın alınması planlanan konuta dair fiziksel özelliklerin ve firmaların sunduklarının konut talebi üzerinde oldukça belirleyici bir etkisi bulunması gerçeği de düşünüldüğünde; konut yapım işi ile uğraşan yüklenicilerin arsa seçiminde ve konut tasarımında özellikle ve öncelikle hedef kitleyi iyi belirleyip, bu kitlenin istek ve beklentileri doğrultusunda şekillenen proje dizaynlarıyla, ulaşım imkânları iyi olan, mümkün olduğunca merkeze yakın yerler seçmeleri gerekmektedir. Örneğin çocuklu ailelerin hedeflendiği bir müşteri kitlesi için park ve okul yakınlarında ya da site içi rekreasyon alanlarının olduğu bir tasarımın yapılması; sanayi bölgelerindeki ihtiyaca yönelik projelerde ise çok odalı geniş konutlar yerine daha küçük, bireyselliğe önem veren ve bireyin gündelik ihtiyaçlarına ev ve iş lokasyonlarından çok uzaklaşmadan tek bir bölge içerisinde karşılayabildiği konutların olduğu tasarımların yapılması ve konutun bu özelliklerinin reklamlarda vurgulanması tüketicinin ilgisini çekecektir.

\section{SONUÇLAR}

Konut sektörü Türk inşaat sektörünün en büyük alt sektörü niteliğindedir. Rekabetin yoğun yaşandığı, risklerin ve belirsizliklerin fazla olduğu inşaat sektöründe firmaların müșteri portföyünü belirleyerek, tüketici ihtiyaçlarına göre konut tasarımları yapmaları yeni konutların satışında firmayı finansal olarak rahatlatacaktır. Konut satışında iyi planlanmış bir pazarlama stratejisi benimsemek firmanın pazarda uzun süre varlığını sürdürmesine de yardımcı olacaktır.

Pazarlama çalışmalarının temelinde "müşteri istek ve ihtiyaçlarının belirlenmesi" yer almaktadır. Konut sektöründe tüketicinin "satın alma davranışı" ilerleyen teknoloji, değişen aile yapısı, büyüyen şehirler gibi unsurlar sebebiyle değişken bir yap1 sergilemektedir. Konut sektöründe akıllı ev sistemlerinin kullanımı, daha küçük aile yapısının ortaya çıkması, günümüz aile yapısında kadının da çalışması, büyüyen şehirlerde ulaşımın gün içinde kapladığı zamanın önemli bir hale gelmesi, sosyal mekanları olan site oturumlarına olan talebin artması, kentsel dönüşüm sonucu yapılan konutların beklentiyi karşılama durumu gibi pek çok unsur da inşaat sektöründe konut satın alma davranışının araştırılmasını gerektirmekte ve değişen koşulların varlığ1 da bu konunun önemini korumasına sebep olmaktadır. $\mathrm{Bu}$ çalışmada konut satın alma davranışı hem mimari yönden değerlendirilmiş, hem de örneklemin demografik özellikleri açısından tüketici tercihlerinin altında yatan sebepler olarak incelenmiştir.

Çalışmada, örneklemin genelini lisans ve lisansüstü eğitim seviyesine sahip bireyler oluşturmaktadır. Eğitim düzeyinin belli bir seviyede olmas1 bireylerin yeni teknolojiler (akıllı ev sistemleri) ve enerji verimliliği (yalıtım) gibi konular hakkında bilgi sahibi olma ihtimalini arttırmakta ve katılımcıların bilinçli tercihler yaptığını düşündürmektedir. Çalışma sonucunda yapılan hipotez testi sonucuna göre katılımcıların eğitim seviyeleri ile konut tercihleri arasında anlamlı ilişki bulunması da bu durumu desteklemektedir. Ayrica cinsiyete göre de konut tercihlerinde farklılık olduğu ortaya çıkmıştır. Özellikle ailelere satış yapmayı hedefleyen firmaların mutfak, banyo ve kiler tasarımına önem vermeleri ve reklamlarında bunu öne çıkarmaları faydalı olacaktır.

Konut pazarlamasında reklam kanalının dışında müşteri ile birebir iletişiminde etkisi büyüktür. 
Hatta asıl satın alma kararı genelde bu birebir görüşmeler esnasında netleşmektedir. Bu noktada tüketicinin kadın ya da erkek oluşuna göre ev ile ilgili vurgulanan özellikler daha da önemli hale gelebilmektedir. Aşağıda tüketicinin çok önem verdiği konular özetlenmiştir.

Çalışma sonucunda orta gelir grubunun genelinin ihtiyaç ya da koşulları iyileştirme sebebi ile konut satın aldığı tespit edilmiştir. Tüketicinin önem verdiği konular incelendiğinde, depremlerin çok yaşandığı ülke koşullarında ilk sırada "deprem yönetmeliğine uygun oluşu" maddesinin bulunması normal karşılanmaktadır. Her bireyin can güvenliğinin en önemli kriter olması ve psikolojik olarak bunun verdiği rahatlık konut satın alma tercihlerine de yansımaktadır. Son yıllarda yapılan yasal düzenlemeler ve yapı denetim sisteminin tüm ülkede uygulanması yeni yapılan konutlarda deprem güvenliği kaygısının önüne geçmektedir. Bununla beraber halen bazı yüklenici firmalar reklamlarında bu konuyu kullanmaktadır. Anket sonuçlarına göre halen tüketicinin "depreme dayanıklılık" ile ilgili vurgulamalara önem verdiği gözlenmiştir. Yüklenici firmalar konut reklamlarında bu konuyu ön plana çıkartmasa bile yine de müşteri ile birebir görüşmeler de bu konunun da vurgulanması olumlu bir etki yaratabilir.

Yüklenici firmaların konutun konumuna karar verirken orta gelir ya da düşük gelir grubu için şehir merkezine daha yakınlık ve ulaşım olanaklarına önem vermesi ve reklamlarında bunu vurgulaması önerilmektedir.

Tüketicinin önem verdiği diğer bir konu da konutun yüzölçümüdür. $\mathrm{Bu}$ noktada konutların verimli kullanılması, depolama imkanının fazla olması ve mekanlara fonksiyona bağlı olarak optimum tefriş elemanın (örneğin bir çocuk odasına; 1 yatak, 1 komidin, bir gardrop ve 1 çalıșma masasının sığması) sığmasına imkan verecek boyutta tasarlanmasına önem verilmesi gerekmektedir.

Doğalgaz tesisat bağlantısının varlığı da konut tercihlerini etkileyen bir unsur olarak öne çıkmaktadır. Sonradan yapılan tadilatlar mevcut malzemeye ve tasarıma zarar verebileceği için satın alınacak konutun doğalgaz tesisatının olması önemli görülmektedir. Yalıtım konusunda özellikle satış esnasında hane başına düşen enerji giderlerinin azaltılmasındaki önemi ve çevreye olumlu etkilerinin vurgulanması önerilmektedir. Yüklenici firmalar tarafından; yalıtımın enerji giderlerine olan olumlu etkisinin vurgulanması tüketicinin de bilinçlenmesine katkı sağlayacaktır.

Yüklenicilerin tüketici tercihlerine göre ürettikleri projeleri uygun reklam çalışmaları ve pazarlama stratejileriyle vurgulaması önerilmektedir.

Çalışma genel olarak orta gelir grubuna uygulanmıştır, çalışmaya alt ve üst gelir grubunun da dahil edilmesi ile sonuçların yüklenici firmalar için daha da aydınlatıcı olacağı düşünülmektedir.

\section{KAYNAKLAR}

1. Su, Ö., 2016. Oturum Amaçlı Konut Pazarlamasında Müşteri Tercihleriyle İlgili Bir Araştırma, İstanbul Aydın Üniversitesi, Sosyal Bilimler Enstitüsü, 101.

2. Şenyurt, Ö., 2001. Konut Pazarlamasında Tüketicinin Satın Alma Davranışları ve Bir Uygulama, Sosyal Bilimler Enstitüsü, 146.

3. Wang, D., Li, S., 2006. Socio-economic Differentials and Stated Housing Preferences in Guangzhou, Habitat International, China, 305-326.

4. Su, Ö., Kaplan, B., 2017. Konut Pazarlamasında Pazarlama Karması Stratejileri Üzerine Bir Araştırma, Bartın Üniversitesi İktisadi ve İdari Bilimler Fakültesi Dergisi, 1-26.

5 Gür, M., Sezer, F.Ş., 2018. Popularity in House Preferences - a Research on Usersatisfaction: Bursa Balat Sample, International Refereed Journal of Design and Architecture, 1-27.

6. E., Mulliner, Algrnas, M., 2018. Preferences for Housing Attributes in Saudi Arabia: a Comparison Between Consumers' and Property Practitioners' Views, Cities, 152-164.

7. Aras Baş, H.K., 2020. Tüketicilerin Konut Satın Alma Davranışlarının Markalaşma Faktörü Kapsamında İncelenmesi, Çukurova Üniversitesi, Fen Bilimleri Enstitüsü, Yüksek Lisans Tezi, Adana, 121. 
8. Koklic, M., Vida, I., 2009. A Strategic Household Purchase: Consumer House Buying Behavior, Managing Global Transition International Research Journal, 75-96.

9. Ö.L., Kellekci, Berköz, L., 2006. Konut ve Çevresel Kalite Memnuniyetini Yükselten Faktörler, İtü Dergisi/a, 167-178.

10. Yalçın, A., Dumanoğlu, S., Alpaslan, H.İ., 2009. Uzun Vadeli Konut Finansmanı Sisteminin (Mortgage) Türk Konut Sektörü İçerisindeki Yeri ve Satınalma Eğiliminin Belirlenmesine Yönelik Uygulama, MUFAD Journal, 74-79.

11. Güremen, L., 2016. Konut ve Yerleşim Alanı Kullanıcı Algısının Memnuniyet ve Tercih Davranışına Etkisi Üzerine Bir Araştırmada Amasya Örneği, Technological Applied Sciences, 24-64.

12. Ratchatakulpat, T., Miller, P., Marchant, T., 2009. Residential Real Estat ePurchase Decisions in Australia: Is it More Than Location?, International Real Estate Review, 273-294.

13. Ayman, H., Al-Momani, 2000. Structuring Information on Residential Building: a Model of Preference, Engineering, Construction and Architectural Management, 179-190.

14. Ayman, H., Al-Momani, 2003. Housing Quality: Implications for Design and Management, J. Urban Planning \& Development, 177-194.

15. Yavuz, S., Çemrek, F., 2013. Konjoint Analizi ile Sağlık Çalışanlarının Konut Tercihlerinin Belirlenmesi, Atatürk Üniversitesi Sosyal Bilimler Enstitüsü Dergisi, 379-396.

16. Karunarathne, L., Ariyawansa, R., 2015. Analysis of House Purchase Intention, Sri Lankan Journal of Management, 28-51.

17. Moghimi, V., Jusan, M., 2015. Priority of Structural Housing Attribute Preferences: Identifying Customer Perception, International Journal of Housing Markets and Analysis, 36-52.

18. Kalaycı, Ş., 2008. SPSS Uygulamalı Çok Değişkenli Istatistik Teknikleri, Asil Yayın, 426.

19. Karakurt Tosun, E., Firat, Z., 2012. Kentsel Mekândaki Değişimler ve Kişilerin Konut
Tercihleri: Bursa Örneği, Business and Economics Research Journal, 173-195.

20. Chia, J., Harun, A., Kassim, A., Martin, D., Kepal, N., 2016. Understanding Factors that in Fluence House Purchase Intention Among Consumers in Kota Kinabalu: an Application of Buyer Behavior Model Theory, Journal of Technology Management and Business, 94-110.

21. Baran, H., 2007. Ailelerin Konut Satın Alma Tutum ve Davranışları Üzerinde Bir Araştırma, Ankara Üniversitesi, Fen Bilimleri Enstitüsü, Yüksek Lisans Tezi, Ankara, 129.

22. Demir, G., 2018. Tüketicilerin Konut Satın Alımını Etkileyen Faktörler Üzerine Bir Araştırma, Toros Üniversitesi, Sosyal Bilimler Enstitüsü, Yüksek Lisans Tezi, 133.

23. Moral, S., 2018. Konut Satım Alımlarında Tüketici Davranışı ve Marka Algısı ile Bilinirliğinin Satın Alıma Etkisi, Maltepe Üniversitesi, Sosyal Bilimler Enstitüsü, Yüksek Lisans Tezi, 96.

24. Karagöz, Y., Eş, A., Yavuz, S., 2015. Nominal İlişki Ölçüleriyle Konut Satın Almaya Etki Eden Faktörlerin İncelenmesi: Bolu İli Örneği, C.Ü. İktisadi ve İdari Bilimler Dergisi, 247-260.

25. Atabeyli, O.C., Keleş, Ş., 2020. Konut Tercihinde Cinsiyet Etkili mi? Davranışsal İktisat ve Rasyonelite Paradoksu, İşletme ve İktisat Çalışmaları Dergisi, 126-145.

26. Memiş, S., 2018. Tüketicilerin Konut Seçimini Etkileyen Faktörlerin Belirlenmesine Yönelik Bir Araştırma, International Journal of Academic Value Studies (Javstudies), 652-665.

27.Zorlu, T., Sağsöz, A., 2010. Müstakil Konut Sitelerinde Kullanıcı Tercihlerine Bağlı Fiziki Müdahaleler: Trabzon Örneği, METU. JFA, 189-206.

28. Trembley, R.K., Dillman, A.D., 1984. Beyond the American Housing Dream: Accommodation to the 1980s, University Press of America, 11(1), 45-46. 
